\title{
Primary Student Teachers' Understanding of Basic Ideas of Nature of Science: Laws, Theories and Models
}

\author{
Constantina Stefanidou \\ Dept. of Education, National and Kapodistrian University of Athens \\ Navarinou 13A, PO Box 10680, Athens, Greece \\ Tel: 30-69-7732-2772Ｅ-mail: sconstant@primedu.uoa.gr \\ Constantine Skordoulis (Corresponding author) \\ Dept. of Education, National and Kapodistrian University of Athens \\ PO Box 10680, Athens, Greece \\ Tel: 30-21-0368-8006_E-mail: kostas4skordoulis@gmail.com
}

Received: Jan. 13, 2017 Accepted: Feb. 18, 2017 Published: February 18, 2017

doi:10.5296/jse.v7i1.10599 URL: http://dx.doi.org/10.5296/jse.v7i1.10599

\begin{abstract}
Nature of Science is an integral part of scientific literacy which researchers and international policy-making institutions highlight as the purpose of science education. The notions of scientific law, theories and models are crucial for understanding the Nature of Science. These notions are better grasped in the historical context of Nature of Science. For this purpose, appropriate instructional sequences, based on semi-structured interviews, were designed and implemented to investigate whether and how the student teachers of Primary Education can perceive these concepts. The study revealed that after particular difficulties were confronted, student teachers were able to grasp firmly the notions of scientific law, theories, models and the relationships among them.
\end{abstract}

Keywords: Nature of Science, History of Science, Laws, Theories, Models 


\section{Introduction}

In recent years there has been more and more interest in the Nature of Science (NoS) in the context of Science Education (SE). Both international policy making institutions (OECD, 2009; AAAS, 1993, 2009, 2013) and researchers in the field of SE ( Hipkins et al., 2005; Lederman, 2006; Matthews, 1992; McComas et al., 1998 and Millar \& Osborne, 1998) emphasize the importance of students understanding of several aspects of NoS. Their rationale for doing so is that if students comprehend how scientific knowledge has evolved, and how the historical, philosophical and technological context influences the development of science then they will gain a more comprehensive view of science and be more actively involved in the relevant cognitive processes.

Features of scientific theories, laws and models constitute components of NoS necessary in SE. The National Science Education Standards in United States (NRC, 1996) underline the importance of students understanding the notion of scientific theory in general and being aware of the procedures whereby scientific explanations and models are formulated and developed, in particular. According to the Science as Inquiry standard, "students' inquiries" are expected to "culminate in formulating an explanation or a model". Moreover, "this aspect of the standard emphasizes the critical abilities of analyzing an argument by reviewing current scientific understanding, weighing the evidence, and examining the logic so as to decide which explanations and models are best" (NRC, 1996, p. 175). In Next Generation Science Standards the notions of scientific theories, laws and models are specified for different levels with specific targets for each. For High School students: "A scientific theory is a substantiated explanation of some aspect of the natural world, based on a body of facts that has been repeatedly confirmed through observation and experiment, and the science community validates each theory before it is accepted. If new evidence is discovered that the theory does not accommodate, the theory is generally modified in light of this new evidence" (NGSS, 2013, p. 99).

Since 1990, in its Science for All Americans document, the AAAS has emphasized students' understanding of theories, laws and models in science, usually in an historical perspective (AAAS, 2013). Its policy document (AAAS, 2009) gives elaborated learning outcomes for every grade, from kindergarten to grade 12 . These documents are widely recognized as a major influence on current efforts to reform SE in the US including the National Research Council's A Framework for K-12 Science Education (2012) and the Next Generation Science Standards (NGSS Lead States, 2013).

Students' acquiring a certain degree of NoS understanding requires science teachers to be knowledgeable on corresponding issues. The literature includes numerous studies on the views of students and science teachers on NoS (Coll et al., 2005; Dagher et al., 2004; Driver et al., 1996; Justi \& Gilbert, 2002; Matthews, 2007; Meyling, 1997 and van Driel \& Verloop, $1999,2002)$ but less on the related teaching approaches. This paper seeks to cover this gap proposing that NoS be explicitly taught in a History of Science context. Didactic sequences were designed, developed and implemented which involved elements of NoS, in particular the terms law, theory and model and the relationships among them. The sequences were 
designed and implemented based on the basis of the History of Science, namely the history of Maxwell's electromagnetic $(\mathrm{e} / \mathrm{m})$ theory. The teaching sequences were applied to university students in the Department of Education (Primary Education). The novelty of the work lies in the fact that an attempt was made to investigate specific difficulties relating to NoS and the corresponding learning processes. The research showed that the students can understand basic points of NoS and an effort to formulate the respective learning processes.

\section{Literature Review}

\subsection{Views on Laws and Theories}

\subsubsection{Pupils' Views on Laws and Theories}

Mackay has pointed since 1971 that pupils do not have sufficient knowledge about the functions of scientific models, the role of theories in scientific research, the distinction between law and theory, and the relationship between model, theory and reality (Mackay, 1971). Scientific theories are probably the most misunderstood aspect of NoS, as they are often considered to be conjecture or very temporary explanations for natural phenomena. Such views also cause difficulties in understanding the way theories are developed and the features of theories that distinguish them from laws but also from non-scientific explanations. A typical student misconception is the view that scientific theories, through continuous control and validation, will eventually mature and become laws (Rubba \& Andersen, 1978; Meyling, 1997). This view has passed into the literature as the "laws are mature theories" myth.

Regarding the law of science, Meyling's study showed a diversity in student responses which mainly relates to the distinction between ontological and epistemological dimensions of scientific law. Specifically, some students present laws as eternal, unchangeable, independent of man, referring implicitly to the ontological dimension of the laws, namely their existence independent of human knowledge of them. In this context, they express the view that laws are inviolable rules that cannot be changed. This makes NoS understanding difficult, since the scientific laws may change in the light of new evidence or theories. The same study also reveals views regarding the epistemological aspect of scientific law, such that the laws formulated by scientists are in doubt and subject to amendment.

Regarding pupils' views on theories, Meyling's study (Meyling, 1997) revealed a prevailing view that theory is completely hypothetical, not yet proven, but it explains. According to another, less dominant view, the theory is a proven set of proposals. A hierarchical relationship in which hypotheses and theories have little certainty while the law has greater certainty was also evident in pupils' views (Lederman \& O'Malley, 1990).

Regarding the relationship between laws and theories, students answered that, on the one hand, laws represent the essential basis for allowing the construction of theories, while on the other, these laws can be the result of a theory, since "a theory when verified becomes law" (Meyling, 1997). 


\subsubsection{University Student and Science Teacher Views on Laws and Theories}

Blanco \& Niaz classified university students' and teachers' views on theories and laws as positivists, transitional or Lakatosian. Most views were positivist and can be summarized as follows: "A scientific theory has not been proved in its totality, whereas a scientific law has not only been proved, but is also universal, and furthermore, a theory tells us about more complex and explicit things" (Blanco \& Niaz, 1997, p. 203). Transitional responses indicated a partial understanding to the existence of competing models for explaining the experimental observations and that no knowledge is ever absolutely established. Lakatosian responses indicated that scientific progress subsumed by process involving conflicting frameworks.

Irez explored the views of science teacher trainers on NoS and revealed inadequate conceptions about NoS: "The majority of these conceptions were concentrated under two aspects of NoS: scientific method and the tentative NoS. The participants' inadequate conceptions appeared to be linked to a lack of prior reflection about NoS" (Irez, 2006, p. 1113). Irez argues that such conceptions relate to conceptions about the relationship between theories and laws. The majority of the educators in this research believed that "proved" theories will become laws, while a law is an unchangeable and final form of scientific knowledge which represents the absolute truth. Brickhouse et al., (2002) focused on how much student understanding of the NoS varied with content. The study suggested that student talk about the NoS differs depending on the particular scientific topic under discussion.

Dagher et al., (2004) explored college students' representations about the nature of theories during their enrollment in a large astronomy course with instruction designed to address a number of NoS issues. After teaching interventions, some students had more comprehensive views on theories and laws. Dagher et al noted that students explicitly emphasize the empirical content of the theory, using terms such as "evidence" and "proof". By the end of their enrollment in the course, students also referred indirectly to other aspects of scientific theory, such as its social and historical dimension. On the other hand, students hardly report any consistency issues in theory building: i.e., deciding whether a particular set of ideas constitutes a scientific theory or not on the basis of the amount of experimental evidence rather than the logic of its structure. These findings coincide with Meyling (1997) and the fact that students find observations and empirical data important is positively estimated. On the other hand, however, Dagher et al., (2004) express the suspicion that the students' emphasis on empirical content may undermine a fuller understanding of the nature of theories, given that their research revealed that none of the students could cope with theories as models that show how the world works.

\subsection{Views on Models}

\subsubsection{Pupils'Views on Models}

According to Grosslight et al. (1991) student conceptions of models were basically consistent with a naïve realist epistemology. Most students perceived models as natural copies of reality rather than as constructed representations which can incorporate a range of theoretical perspectives. Models were very rarely mentioned as representations of ideas or abstract 
entities. Older students displayed a little more familiarity with two-dimensional models such as charts, maps and sketches.

Most students considered a model's main aim to be to facilitate observations, teaching, learning and communication by interpreting and simplifying. When asked if a scientist can change the model, younger students expressed the view that the model could be changed "if it wasn't right". Older students argued that models change in light of new evidence. No student clearly expressed the view that models play an active role in the production of scientific knowledge.

Treagust et al. identified five themes about students' understanding of scientific models: "scientific models as multiple representations; models as exact replicas; models as explanatory tools; how scientific models are used; and the changing nature of scientific models" (Treagust et al., 2002, p. 357). Regarding the models' role and purpose, research shows that while most students can grasp the descriptive role of models, they do not display a comparable grasp of the predictive role of models and the role they play in developing scientific ideas. Greater emphasis on the teaching of the role and purpose of the concept of scientific models is suggested.

Regarding the relationship between theories and models, the research shows that students connect theories with models more through the representational function of the latter and far less through models' function as theory development tools (Treagust et al., 2002, p. 365). The majority of students recognize that models are structures that support scientific theories and therefore may change if scientific thought changes. However, while students recognize that models may change if new theories or evidence emerge, they do not attribute an active role in theory construction to models.

According to Aikenhead and Ryan (1989) students hold the view that models are not copies of reality, but close to reality. There is indeed a tendency across almost all the research for students to link models with reality, with the link to the development of ideas and theories far less prominent.

\subsubsection{University Student and Science Teacher Views on Models}

Justi \& Gilbert conducted a survey of science teachers' views on models. Seven aspects of their notions of models were revealed: "the nature of a model, the use to which it can be put, the entities of which it consists, its relative uniqueness, the time span over which it is used, its status in the making of predictions, and the basis for the accreditation of its existence and use" (Justi \& Gilbert, 2003, p. 1369). The results do not confirm profiles of understanding. According to the authors, the absence of such profiles in the teachers' thinking suggests that they probably do not hold coherent ontological and epistemological views on models. If so, this would support the work of Koulaidis and Ogborn in the broader field of the nature of science (Koulaidis \& Ogborn, 1989, p. 1382).

Van Driel and Verloop concluded that while experienced science teachers agree on the general idea that the model is a simplified representation of reality, they have quite different views on models and modeling in science (van Driel \& Verloop, 1999). Specifically, the 
results showed a wide range of criteria used by teachers to categorise specific examples as models or not, as well as a tendency to emphasize different features of models. Moreover, some functions of models were rarely reported: their predictive role, for instance, or their use in approaching and learning to study systems to which you have no direct access.

Justi and Gilbert conducted a survey of science teachers' views on the role of models in science teaching. The results show that teachers had insufficient knowledge both of the nature of models and of how to use models in the educational process. They also suggest that science teachers should be systematically trained in models and their use (Justi \& Gilbert, 2002).

\section{Research Design and Procedure}

\subsection{The Purpose of the Study}

The study reported here is an enquiry into student teachers' (primary education) understanding of basic ideas of NoS. The study aims to investigate the student teachers' teaching and learning procedures in relation to the notions of laws, theories, models and the relations among them in a context of NoS. Maxwell's electromagnetic $(\mathrm{e} / \mathrm{m})$ theory and the corresponding laws and models were introduced as teaching material. In this context, the questions were the following:

a. To what extent are the student teachers able to construct the scientifically accepted view about the notions of laws, theories and models in the context of NoS?

b. Which are the teaching and learning procedures of the student teachers regarding the notions of laws, theories and models and the relations among them in the context of NoS?

\subsection{Participants}

The study was carried out in the University of Athens' Department of Primary Education. The sample group consisted of 40 student teachers divided into 11 groups of 3-4 students each. Regarding the educational background of the student teachers, they were all third year university students who had studied a Physics course but no course on the Epistemology of Science. During the Physics course, they were taught basic electromagnetism and the physical significance of Maxwell's equations, including in particular the description of the $\mathrm{e} / \mathrm{m}$ wave. Moreover, the students attended a laboratory course, which accompanied the Physics course and included experiments in the area of electromagnetism. As a result, the sample group was quite familiar with the phenomenon of $\mathrm{e} / \mathrm{m}$ induction both theoretically and experimentally.

In the Greek educational system, graduates of the Department of Primary Education are authorized to teach all six levels of primary education, starting at the age of six. Regarding SE, environmental studies are taught during the first four years of primary school, while Physics is taught during the last two years.

\subsection{Teaching material}

The concepts of laws, theories and models were discussed in the historical context of James 
Clerk Maxwell's e/m theory. Worksheets were used to negotiate these concepts and the relationships among them. The worksheets were essentially supporting material for the semi-structured interviews presented below. The material contained pictures and short excerpts from selected historical texts mainly Maxwell's first two works On Faraday's Lines of Force (1856) and On Physical Lines of Force (1862) which are mostly descriptive and include less formalism than the works that followed: A Dynamical Theory of Electromagnetic Field (1865) and Treatise on Electricity and Magnetism (1873).

The decision to choose Maxwell's e/m theory and its historical reconstruction as teaching material was based on the following points:

- Greek students are familiar with e/m theory from their secondary formal education. The relevant laws (e.g., e/m induction) are taught in Primary education (Grade 5 and 6) via a qualitative and experimental approach, meaning an approach that includes experiments but no mathematical equations. In secondary education, students are taught the laws of electricity and magnetism using simplified mathematical formalism. Thus, even students who choose a theoretical direction have already been taught the relevant laws of e/m theory at many phases of their studies. In terms of tertiary education, e/m theory is part of Physics, which is included in their curriculum as a compulsory subject. Therefore, students are highly familiar with the content of $\mathrm{e} / \mathrm{m}$ theory and the correspondent laws.

- Furthermore, Maxwell's e/m theory has an appropriate structure to be considered a model of "good" theory (Kalkanis, 2002, p. 179). Specifically, it has the explanatory power that a good theory must have, since it explains the whole of e/m phenomena. Moreover, it has predictive power, since through it Maxwell predicted the nature of light. Regarding its relationship with laws, e/m theory not only contains laws but it also explains Faraday's law of $\mathrm{e} / \mathrm{m}$ induction and completed Ampere's law on the magnetic field around a current-carrying conductor. As for the predictive nature of the theory, the wave equation of light resulted from theorizing electromagnetism. Regarding the relationship between theories and models, the historical reconstruction of electromagnetism depicts not only the representational role of models but also their heuristic role in theory construction. Maxwell's vortex model became a case study for demonstrating the active role of models in the formation of theories. Regarding the relationship between laws and mathematical models (i.e., equations), e/m theory includes laws, such as Ampere's law, which evolved through mathematical logic to include other phenomena.

In the next section, it is presented how the specific elements of e/m theory, its respective laws and models were used as teaching material to investigate teaching and learning processes relating to laws, theories and models in the context of NoS.

\subsection{Teaching Sequence}

Taking into account the results of the literature review, a teaching sequence consisting of six interviews was developed. The topics of each session were as follows:

$1^{\text {st }}$ Interview: Laws of nature

$2^{\text {nd }}$ Interview: Scientific theory 
$3^{\text {rd }}$ Interview: Scientific model

$4^{\text {th }}$ Interview: Relationship between models and theories

$5^{\text {th }}$ Interview: Relationship between laws and theories

$6^{\text {th }}$ Interview: Relationship between laws and models

Appendix 1 details the scientific content of each interview, the steps followed, and the related educational materials.

\subsection{Research Instruments}

\subsubsection{Pre and Post Questionnaire}

They consisted of eight open-ended questions in the spirit of VNOS-A (Lederman \& O'Malley, 1990), VNOS-B (Abd-El-Khalick et al., 1998) and VNOS-C (Abd-El-Khalick \& Lederman, 2000). It was completed by the students before and after the teaching sequence.

\subsubsection{Three sessions}

Every session lasted three lesson hours, conducted with week intervals, regarding the notions of theories, laws and models and the relationships among them. The first session consisted of three interviews (notions of laws, theories and models), the second session consisted of one interview (relation between models and theories) and the third session consisted of two interviews (relationship between theories and laws and laws and models). Interviews were videotaped, transcribed and analyzed.

\subsubsection{Six worksheets}

They consisted of material appropriate for the development of the interviews. During the second and third session, the material was mostly consisted of historical excerpts and pictures, from e/m theory.

\subsection{Data collection}

In order to collect the data, experimental interviews (the so-called "teaching experiment") were used (Komorek \& Duit, 2004). The teaching experiment is a kind of interview that is deliberately employed as a teaching and learning situation. The interviewer assumes the roles of a classical interviewer, who tries to understand students' individual conceptions, and a teacher, who must have answers to students' conceptions and make the appropriate intervention at just the right moment (Stavrou et al., 2008). According to Komorek and Duit (2004), the teaching experiment has proven to be a powerful means of investigating the convergence of student conceptions with the scientifically accepted point of view.

Specifically, when working with small groups (groups of three or four students in our case), "he/she (teacher-interviewer) is responsible for supporting the interaction among the students and only intervenes when the student-student interaction is no longer fruitful" (Komorek \& Duit, 2004, p.629). This approach was chosen because it "provides a teaching character which facilitates modeling learning in real classroom settings" (Komorek \& Duit, 2004, p. 630). Students were divided into 11 groups of 3-4 persons each. Each group took part in six interviews and each interview lasted from one to three lesson hours. The first author carried 
out the teaching experiments. The sessions were audio-taped and transcribed.

Students also had to complete two questionnaires individually - one before and the other after the end of the teaching experiments. The questionnaires were used supportively to reveal students' conceptions about the concepts under consideration.

\subsection{Data Analysis}

Qualitative content analysis methods were used (Mayring, 2000; Erickson, 1998) given the explorative character of the present study. The data were derived from the questionnaires and from the interviews: the students' answers to the pre and post questionnaires were indexed and categorized according to their content, while the interviews were transcribed, they were separated into steps. These steps correspond to the phases of the teaching experiment as described in the teaching and learning sequence section. For every phase, students' arguments, ideas, difficulties and the ways these difficulties are surpassed, if they are, were noted down and grouped according to their answers. Finally, an attempt was made to describe students' learning pathways towards a scientifically accepted point of view.

\subsection{Limitations of the research}

The limitations of the research arise mainly from its explorative character. Its results arise from a limited and convenient sample and can in no way be generalized to the population as a whole. The purpose of implementing the Teaching Experiment was the in-depth investigation of learning processes in relation to the issues under consideration and not the export of generalizable quantitative conclusions. The research is purely qualitative. Like all qualitative research, it involves the subjective factor - in this case, the interpretations of the researchers, who designed and implemented the research but also analyzed the data and drew conclusions. The data obtained were written documents and transcripts of interviews which, were classified and analyzed as described above.

\subsection{Findings and Results}

\subsubsection{Pre - Post Quantitative Results}

In the following tables, Pre and Post questionnaire results are presented in terms of absolute frequencies. Acceptable but not complete answers are marked in bold. For example, "A scientific law is experimentally confirmed" is part of a complete answer and is classified in the category "empirical content".

Scientific law: Table 1 shows that most students' initial view (25/39) was that scientific laws are inflexible and cannot be questioned. Some students (10/39) gave answers which were beyond any classification. Very few of them (4/39) gave scientifically acceptable but not complete answers. After the teaching experiment $\left(1^{\text {st }}\right.$ interview $)$, the majority of the students (27/39) were able to formulate a complete view of scientific law or at least to include its most important features. 
Table 1. Scientific law

\begin{tabular}{|l|c|c|}
\hline & \multicolumn{1}{|c|}{$\begin{array}{c}\text { PRE-TEST } \\
\text { (absolute frequency) }\end{array}$} & $\begin{array}{c}\text { POST-TEST } \\
\text { (absolute frequency) }\end{array}$ \\
\hline Complete answer & 0 & 27 \\
\hline $\begin{array}{l}\text { Law has universal } \\
\text { character, related to natural } \\
\text { phenomena }\end{array}$ & 0 & 12 \\
\hline $\begin{array}{l}\text { Law governs nature and } \\
\text { does not change }\end{array}$ & 25 & 0 \\
\hline Empirical content & 4 & 0 \\
\hline Other answers & 10 & 39 \\
\hline Total & 39 & 0 \\
\hline
\end{tabular}

Scientific theory: The results in Table 2 reveal that although initially most students (20/39) could give an answer including accepted features of scientific theory, no student could give a complete answer. The predictive role of theories was not mentioned at all. The post questionnaires showed that most students (32/39) could give a complete answer, including both explanation and prediction, while the students that could not, could give at least some accepted features.

Table 2. Scientific Theory

\begin{tabular}{|l|c|c|}
\hline & $\begin{array}{c}\text { PRE-TEST } \\
\text { (absolute frequency) }\end{array}$ & $\begin{array}{c}\text { POST-TEST } \\
\text { (absolute frequency) }\end{array}$ \\
\hline Complete answer & 0 & 32 \\
\hline Tautology scientific & 19 & 0 \\
\hline $\begin{array}{l}\text { Outcome of } \\
\text { method }\end{array}$ & 14 & 7 \\
\hline Explanation & 6 & 0 \\
\hline Total & 39 & 39 \\
\hline
\end{tabular}

Scientific model: Regarding models (Table 3), most of the students (22/39) initially had the view that they play a representative role (representing either a theory or a physical system), which is an accepted view but not a complete one. A small number of students (4/39) attributed to models a more active role in theory construction. After the teaching experiment $\left(3^{\text {rd }}\right.$ interview) all the students could formulate a view including the representational role of modelS (theories, physical systems, ideas, processes) and their simplifying and explanatory role, as well. 
Table 3. Scientific model

\begin{tabular}{|l|c|c|}
\hline & $\begin{array}{c}\text { PRE-TEST } \\
\text { (absolute frequency) }\end{array}$ & $\begin{array}{c}\text { POST-TEST } \\
\text { (absolute frequency) }\end{array}$ \\
\hline Complete answer & 0 & 39 \\
\hline Represent a theory & 11 & 0 \\
\hline Represent (in general) & 11 & 0 \\
\hline Outcome of scientific method & 10 & 0 \\
\hline $\begin{array}{l}\text { The base for developing a } \\
\text { theory }\end{array}$ & 4 & 0 \\
\hline Other answers & 3 & 39 \\
\hline Total & 39 & 0 \\
\hline
\end{tabular}

Relationship between scientific theories and models: Initially, the dominant view (24/39) regarding the relationship between theories and models (Table 4) was that models represent theories, which is an accepted but incomplete answer. After the teaching experiment $\left(4^{\text {th }}\right.$ interview), the majority of the students (34/39) gave a complete answer including both the representational function of models and their active role in theory construction.

Table 4. Relationship between scientific theories and models

\begin{tabular}{|l|c|c|}
\hline & $\begin{array}{c}\text { PRE-TEST } \\
\text { (absolute frequency) }\end{array}$ & $\begin{array}{c}\text { POST-TEST } \\
\text { (absolute frequency) }\end{array}$ \\
\hline Complete answer & 0 & 34 \\
\hline Models represent theories & 24 & 5 \\
\hline $\begin{array}{l}\text { Theories derive from the } \\
\text { models }\end{array}$ & 7 & 0 \\
\hline $\begin{array}{l}\text { Their relationship is } \\
\text { bidirectional }\end{array}$ & 4 & 0 \\
\hline Other answers & 4 & 39 \\
\hline Total & 39 & 0 \\
\hline
\end{tabular}

Relationship between scientific laws and theories: The results (Table 5) reveal that nearly half the students (18/39) gave answers including the view that theories are based on laws or explain laws, which is an accepted but incomplete view. Some (14/39) gave answers that included the idea of laws being superior and unquestionable, compared to theories which can change very easily. This very persistent idea was taught thoroughly during the $5^{\text {th }}$ experimental interview. Ultimately, the majority of students (25/39) could give complete answers, though some (14/39) answered incompletely, focusing on the different functions of laws and theories in that laws describe phenomena and theories explain them. 
Table 5. Relationship between scientific laws and theories

\begin{tabular}{|l|c|c|}
\hline & $\begin{array}{c}\text { PRE-TEST } \\
\text { (absolute frequency) }\end{array}$ & $\begin{array}{c}\text { POST-TEST } \\
\text { (absolute frequency) }\end{array}$ \\
\hline Complete answer & 2 & 25 \\
\hline $\begin{array}{l}\text { Theories are based on laws } \\
\text { and explain them }\end{array}$ & 18 & 0 \\
\hline $\begin{array}{l}\text { Scientific laws describe } \\
\text { phenomena while theories } \\
\text { explain them }\end{array}$ & 0 & 0 \\
\hline $\begin{array}{l}\text { Scientific laws are more valid } \\
\text { than theories }\end{array}$ & 14 & 0 \\
\hline Other answers & 5 & 39 \\
\hline Total & 39 & 0 \\
\hline
\end{tabular}

Relationship between scientific laws and models: Regarding the relationship between scientific laws and models (Table 6), initially, most students (22/39) focused on the representational role of models, which is accepted but incomplete. After the teaching experiment $\left(6^{\text {th }}\right.$ interview) the majority of students $(35 / 39)$ could formulate a complete answer which recognized that models represent laws but can also lead to further conclusions.

Table 6. Relationship between scientific laws and models

\begin{tabular}{|l|c|c|}
\hline & $\begin{array}{c}\text { PRE-TEST } \\
\text { (absolute frequency) }\end{array}$ & $\begin{array}{c}\text { POST-TEST } \\
\text { (absolute frequency) }\end{array}$ \\
\hline Complete answer & 0 & 35 \\
\hline Models represent laws & 22 & 4 \\
\hline Models are laws & 3 & 0 \\
\hline Other answers & 14 & 0 \\
\hline Total & 39 & 39 \\
\hline
\end{tabular}

\subsection{Learning Difficulties}

Analysis of the teaching experiment showed that most students were able to handle the basic ideas of NoS, and specifically the notions of laws, theories and models. For research confidentiality reasons, in the following quotations the number indicates the number of the group and the letter indicates the position of the student in the group (i.e., 10A means that it's the tenth group and the first student in that group). By the end of the process, all the groups had formed a scientifically accepted view about the notion of:

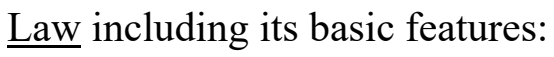

10 A: "(Law) has universal and enduring power. It expresses some kind of natural necessity resulting from observations and experimentation. It is valid within limits".

9 A: "(Law) is universal in space and time. It must relate to a natural phenomenon and is empirical in character".

Theory including its basic features: 
$9 \mathrm{C}$ : "A scientific theory is a set of proposals which consolidates several existing knowledge. It attempts to interpret this knowledge holistically, to explain it and to make assumptions and predictions".

13 D: "A scientific theory is a set of assumptions based on previous observations and experimentation. It seeks to link to and explain earlier theories and leaves space for further research".

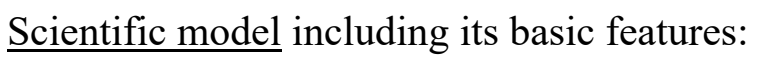

3 B: "A scientific model is a representation of a phenomenon or physical system or theory which is simplified and is intended to assist in understanding and better observing such systems. It differs from the object itself. It is simplified".

$6 \mathrm{~B}$ : "A scientific model is the representation of a system, a function [...] associated with natural phenomena; it seeks to explain and simplify theories and phenomena. It may be a physical object but also a mental representation".

Moreover, the majority of the students could deal with the relationships between laws, theories and models. Specifically, regarding:

The relationship between theories and models:

8 B: "Models and theories have a dynamic relationship. That means that theories can be formed alongside models, as in Maxwell's case. Theories can also predate models or vice versa, depending on the case. Models usually help us understand something that we cannot perceive with our senses in everyday life and evolve in the course of our experimentation. Finally, a good model is one that describes the theory; the theory may also be partly based on the model".

6 D: "The scientific model does not always have the same relationship with the scientific theory. Sometimes the model is a solid basis on which to build a theory, as here with Maxwell. Sometimes it serves an auxiliary role, supporting a theory. It can also help represent something which we cannot understand with words alone".

The relationship between scientific theories and laws:

3C: "The law is the basis for the formulation of a theory... [It is] the foundation. Also a theory can result in a new law. Finally, the theory can extend the law to enrich and explain it".

3 A. "Yes, a scientific theory contains laws, but it also explains laws $[\ldots]$ corrects $[\ldots]$ and can through a theory $[\ldots]$ can arise a new law".

The relationship between laws and models:

4 D: "The mathematical expression of a law helps us to draw our conclusions from the law more easily. It is something more than a summary. A mathematical model may complete the corresponding law [...] it may say something extra [...] [or] help scientist to develop his/her knowledge on the issue, to go further".

$3 \mathrm{C}$ : "Equations not only describe the laws, they also make them more convenient. Mathematical models can sometimes help laws to be extended". 
However students faced some difficulties during the process, mainly relating to their perception that:

(a) A scientific theory is less reliable and valid than a law, which is more certain and valid.

(b) A scientific law has no limits to its implementation.

(c) Description and explanation are the same.

(d) Scientific theories should be proven experimentally.

(e) Models have an exclusively representational role.

It seems that these difficulties worked as conceptual barriers for students and an attempt was made during the teaching experiments to help the students deal with them. Students' conceptions and their learning processes in relation to the relevant issues are presented analytically below.

\subsubsection{The definite nature of a law compared to theory}

Students initially believed that laws are a more reliable form of scientific knowledge than theory. This view ran through almost all the interviews and stems from misconceptions in relation to laws, theories and the relationship between them. Students compared laws with theories and had developed the view that a well-founded theory will become law when it is well-documented. At the same time, however, this idea prevented them from seeing the real difference between laws and theories, which relates neither to validity nor quality but rather to function. This view seemed to be the root cause of the following additional difficulties the students experienced.

\subsubsection{A scientific law has no limits on its implementation}

Students, in the first interview, expressed the view that laws are "true" and do not change. They had difficulty accepting that the validity of the law is limited. When asked whether the law can be amended, they responded that it could not; as they saw it if it was modified it would become a theory. According to students, laws were not questionable forms of knowledge, though theories were. During the teaching experiment, examples of famous laws which have limits and which do not hold for any value or conditions were discussed. Students gradually realized that the laws formulated by scientists have limited application and can change in light of new evidence. Progressively, this would become a distinction between the laws formulated by empirical scientists (the epistemological dimension of law) and laws that may apply in nature irrespective of our knowledge of them (the ontological dimension of law). Laws made by scientists are the best descriptions of phenomena: they may have specific limits within which they apply, and they change given new evidence.

\subsubsection{Distinguishing description from explanation}

After understanding the limits of scientific laws, students found that the validity of laws is not a given and proceeded to learn the functions of scientific theories (2nd interview). Through Maxwell's e/m theory, students developed and elaborated the features of a scientific theory. It was at this point that the difficulty in distinguishing the concepts of description and explanation arose. The two concepts, description and explanation, are central to developing 
the concepts of laws and theories respectively. Thus, students are confronted with a question; since Faraday had made and experimentally confirmed the law of e/m induction, what was Maxwell's role in this law? Introducing suitable historic material, students realized that what Maxwell intended was to explain Faraday's law.

The term explanation is a very complex term in the philosophy of science. The presentation and analysis of the different theories of scientific explanation go beyond the scope of this study. Within this research, explanation is different from description in so far as explanation provides a coherent mechanism for relating all the observations or data concerning a natural phenomenon or similar natural phenomena. This mechanism not only provides details on existing phenomena: it can also be used to make predictions.

Thus, through discussion and historical examples students were able to discern that while Faraday had described and confirmed experimentally the phenomenon of e/m induction, Maxwell was looking for the root cause i.e., the mechanism for generating electric current by changing the magnetic field. We discussed with students the modern explanation of e/m induction, i.e., e/m wave, in order to differentiate description and explanation directly. The students gradually formed the view that laws have descriptive value while theories have explanatory value.

\subsubsection{Theories' experimental "proof"}

Several students expressed the view, either directly in the pre questionnaires or during the interviews, that theories are experimentally "proven" proposals. Even those who thought that the difference between law and theory is that the theory is not "proven" in the same way as law is, when asked "What is a scientific theory?" they responded that "It is the result of experimental "proof"” or "It is scientifically "proven"'”. It seems that students consider a theory to be scientific only if it is "experimentally proven". It also seems that students have difficulty in managing the empirical character of theories. The point is that this particular perception prevented them from understanding the role of theories that goes beyond the explanation of the phenomena, the prediction of new phenomena and laws (2nd interview). Thus, students came into contact with Maxwell's writings and gradually found out that his work was based on his colleagues' numerous and diverse observations and comments. He tried to combine all these findings into a single theoretical framework, and the result of his research on $\mathrm{e} / \mathrm{m}$ phenomena was the explanation which included the e/m wave, a theoretical concept that has not yet in Maxwell's era been confirmed experimentally. Furthermore, students gradually saw that the e/m theory of light was a successful prediction attributed to Maxwell's e/m theory. The scientist who made this prediction had not had the opportunity to confirm it experimentally. Thus, students concluded that although a theory is based on empirical data, the experimental "confirmation" of a theory is not a criterion in whether the theory is scientific or not. The purpose of a fertile theory is to predict phenomena and/or corresponding laws that can be verified or refuted in subsequent investigations.

After clarifying the empirical character of theory, the discussion on the relationship between laws and theories ( $5^{\text {th }}$ interview) seemed to be easier and more productive. Thus, while in the pre questionnaire, students gave answers limited to theories including and explaining laws, 
when asked the same questions at the start of the fifth interview, they had already developed the necessary background to be able to shed light on other aspects of the relationship between laws and theories. Thus, discussing Maxwell's e/m theory and related laws, students were able to discern that theories, apart from explaining laws, can also correct and complete laws. Ampere's law is a good example of this, which Maxwell managed to complete - including in it the creation of magnetic field by changing electric field - using purely theoretical tools. Eventually, students not only overcame their difficulty in regard of the experimental "confirmation" of theories, but they also managed to grasp the prediction of new laws as a feature of theories.

\subsubsection{Models have an exclusively representational role}

Students had the view that models have an exclusively representational role (3rd interview). In their initial descriptions, the idea that modeling is a sort of knowledge production process was completely absent. Students could not conceive other functions for models, such as the gradual formulation of explanations or hypotheses for the development of a phenomenon or a theory. The students' views negatively influenced their views on the relationship between theories and models (4th interview), since they believed that this relationship boiled down to the model simply representing a scientific theory. They did not recognize that the model can play an active role in helping the scientist to develop his thinking. Through material from the history of science, specifically Maxwell's model and the corresponding theory, students found out that the construction of a model takes several steps and plays a role in the construction of ideas and - ultimately - a theory. Maxwell's vortex model helped him formulate his theory, not just represent it. Students were faced with the same difficulties Maxwell confronted when formulating his model but also told how he overcame these difficulties. Through their engagement with the mechanical problems of Maxwell's vortex model, students managed to reverse and broaden the relationship between scientific theory and models.

Overcoming this difficulty had direct positive effects on their negotiating of the relationship between mathematical models and laws (6th interview). This negotiation revealed an active role for mathematical models and not just a role in describing laws using mathematical language. Using appropriate activities based on Faraday's and Maxwell's historical excerpts, students were able to construct the idea that the use of mathematical models ensures precise description and facilitates the deduction of further conclusions.

\section{Conclusion}

In the present study, an attempt was made, firstly, to investigate the extent to which primary student teachers are able to construct the scientifically accepted views on the notions of laws, theories and models in the context of NoS and, secondly, to investigate the adequacy of teaching and learning procedures regarding the notions of laws, theories and models and the relations among them in the context of NoS. Identifying and addressing students' difficulties was crucial to the negotiation of these notions. Teaching sequences were designed and implemented using historical material from Maxwell's e/m theory.

The empirical research shows that primary student teachers can understand the basic features 
of laws, models and theories. They can also use these concepts to develop adequately relationships among them. The findings of this study show that students' learning processes were affected by difficulties in specific subjects. These difficulties were: (a) Recognizing the definite nature of the law compared to the theory; (b) Recognizing that a scientific law has no limits to its implementation; (c) Distinguishing description from explanation; (d) Recognizing the role of theories' as experimental "proof"; (e) Recognizing models' exclusive representational role.

To be more specific, students' perception that laws are more valid than theories - which is also mentioned by Mackay (1971), Rubba \& Andersen (1978), Meyling (1997), Blanco \& Niaz (1997), Irez (2006) and Akerson \& Hanuscin (2007) - appears to impact on all the issues under discussion. According to this perception, the difference between laws and theories lies in their degree of validity and not in their different functions; as a result, students believe that mature theories become laws. This belief that laws have "absolute power" and do not change then prevents an understanding of the temporary nature of scientific knowledge. When students are gradually confronted with examples of well-known laws which do not apply to the full range of values, they are forced to accept that laws have limits on their power and to conclude that laws of science, as well as theories and models, are subject to control and can change in the light of new evidence. They thus conclude that whether there are some laws in nature which are independent of our knowledge of them or not, the laws made by the scientists are the best possible descriptions of our world and can be changed or corrected if new theoretical or experimental data occurs. After students have overcome this difficulty, they are more ready to develop the relationship between laws and theories.

Regarding students' difficulty distinguishing between description and explanation, they initially seem to have mixed up Maxwell's role in the phenomenon of e/m induction and Faraday's experimental confirmation of that phenomenon. Through historical quotes and appropriate questions, the students ascertained that while Faraday had described the phenomenon of $\mathrm{e} / \mathrm{m}$ induction, he had not given a complete answer on the mechanism behind it, and that it was Maxwell who did that. Provided with the modern explanation of the phenomenon, which is the e/m wave, students concluded that Faraday had described the phenomenon but had not explained it. The explanation of the phenomenon through the e $/ \mathrm{m}$ wave is attributed to Maxwell, ending the distinction between description and explanation.

The students' view that theories are scientifically "proven" was projected when they wanted to justify the scientific character of theories and to focus on the contrast between theories and laws, which they consider as mere "cases". Such contradictions - which reveal difficulties in managing the empirical component of theories - have also been mentioned by Dagher et al., (2004). Both cases - whether learners consider theories as necessarily confirmed or as mere hypotheses - lead to further difficulties: if students claim that the theory must necessarily be confirmed, they leave little room for further prediction through theories. This finding correlates with corresponding investigations (Meyling, 1997; Dagher et al., 2004).

Through discussion and a breakdown of Maxwell's texts, students distinguish the fact that "light is an electromagnetic wave" was a prediction of Maxwell's e/m theory which resulted from a combination of observations and mathematical thinking. Experimental confirmation of 
this fact was achieved several years later. Thus, the students gradually attribute the characteristic of prediction to theory.

Once the students had overcome their previous difficulties, they were able to develop gradually the relationship between laws and theories and express the view that theories explain laws - relating to the difficulty of distinguishing between description and explanation, theories may correct or add to a law - relating to the difficulty of laying down the limits on law's implementation, and theories may establish new laws - relating to students' difficulties with the experimental proof of theories.

Finally, students had difficulty understanding models' other functions beyond representation. This is highlighted by Grosslight et al., (1991), Meyling (1997) and Treagust et al., (2002). Maxwell's modeling processes gradually made students conclude in their descriptions of models that models play an active role in the construction of theories as well as playing a representational role; they contribute to the process of theory development, since scientists' thinking is facilitated by modeling.

The following findings also emerged. Many students gave answers that reveal epistemological contradictions. For example, they may answer that laws are more confident than theories because they are "proven" while theories aren't and then go on to argue that scientific theories are scientifically "proven" proposals. It seems that they cannot decide on the role of empirical data in the description of laws and theories. Corresponding findings emerged from the research of Koulaidis and Ogborn (1995).

Most students do not distinguish the notions of "proof" and the experimental verification. Thus, while proof is a mathematical term denoting a logical conclusion, experimental verification is some kind of strong evidence that a theory or law applies. However, the possibility that the theory can be disproved by subsequent experiments still exists. The fact that students used the terms confirmation and proof interchangeably is revealing of the difficulties they have handling the distinction between them. This was also observed by Dagher et al., (2004), which suggested an explicit distinction between the terms.

\section{Further research}

The study indicates that there is still a good deal that needs to be investigated in depth with regard to NoS in primary and secondary education but also tertiary education. The implementation of classroom research is highly recommended. Following adaptation according to each level of education and updating based on the findings of the present research, such research could provide further evidence for effectively teaching NoS elements in a broader educational context.

However, since the field of investigation was quite extended in terms of subjects under consideration, it is suggested that future research focus on specific issues, particularly:

1. The concept of law in different science subjects (i.e., Physics, Chemistry, Biology). For example Faraday's law has different characteristics from Mendel's law in Biology. The exploration of these differences would highlight similarities and differences of science subjects. 
2. Exploring multiple significations of certain terms used in science and in everyday life. Words such as 'law', 'theory', 'explanation', 'hypothesis' etc., seem to affect and often interfere with students' ability to understand scientific concepts. The understanding of these terms is perhaps a prerequisite to understand the content science.

3. Exploring the triptych laws, theories and models as a framework of understanding other aspects of the NoS; i.e., the fact that science is based on experimental data, the difference between indication and inference, or the socio-cultural context of science. As one student put it: "The truth is that, in the end, I understood that science is a team sport which isn't necessarily only played in a laboratory conducting experiments. There are other factors that influence the production of scientific knowledge ... It may not be a coincidence that Faraday was poor and mathematically illiterate, while Maxwell was wealthy. "

4. Exploring NoS as a framework for understanding science itself. Understanding concepts such as the difference and the relationship between the notions of theory and law helps to create the proper conditions for particular laws and theories to become more comprehensible. As one student said: "If you do not know the whole, i.e., what is a scientific law in general, how are you supposed to learn the parts? For example Faraday's law? ".

5. Finally, the study indicates a need for further research into the correlation between students' attitudes towards science with the history of science. In one student's words: "Who would expect that we would enjoy working with Maxwell? ... Personally, now that I've started to understand, I will stay involved with science and its history, it's amazing!”

\section{References}

Abd-El-Khalick, F., \& Lederman, N. (2000). The influence of history of science courses on students' conceptions of the nature of science. Journal of Research in Science Teaching, $37(10)$, 1057-1095. https://doi.org/10.1002/1098-2736(200012)37:10<1057::AID-TEA3>3.0.CO;2-C

Abd-El-Khalick, F., Bell, R., \& Lederman, N. (1998). The nature of science and instructional practice: Making the unnatural natural. Science Education, 82(4), 417-436. https://doi.org/10.1002/(SICI)1098-237X(199807)82:4<417::AID-SCE1>3.0.CO;2-E

Akerson, V., \& Hanuscin, D. (2007). Teaching Nature of Science through Inquiry: Results of a three years Professional Development Program. Journal of Research in Science Teaching, 44 (5), 653-680. https://doi.org/10.1002/tea.20159

$\begin{array}{lcrrr}\text { American } & \text { Association } & \text { for } & \text { th(Online }) & \text { Available: } \\ \text { http://www.project2061.org/publications/bsl/online/index.php } & \text { (January } & 20, & \text { 2017)e } \\ \text { Advancement of Science. }(1993, \text { 2009). Benchmarks Online. } & & \end{array}$

American Association for the Advancement of Science. (2013). Science for all Americans. 
(Online) Availble: http://www.project2061.org/publications/sfaa (January 20, 2017)

Anapolitanos, D., Arabatzis, Th., Karakostas, V., \& Kindi, V. (2003). Evolution of Ideas in Natural Sciences. Patra: Greek Open University Press (In Greek).

Blanco, R., \& Niaz, M. (1997). Epistemological Beliefs on Students and Teachers about the Nature of Science: from "baconian inductive ascent" to the "irrelevance" of scientific laws. Instructional Science, 25(3), 203-231. https://doi.org/10.1023/A:1002992204311

Brickhouse, N., Dagher, Z., Shipman, H., \& Letts, W. (2002). Evidence and Warrants for Belief in a College Astronomy Course. Science \& Education, 11(6), 573-588. https://doi.org/10.1023/A:1019693819079

Coll, R., France, B., \& Taylor, I. (2005). The role of models and analogies in science education: implications from research. International journal of science education, 27(2), 183-198. http://dx.doi.org/10.1080/0950069042000276712

Dagher, Z., Brickhouse, N., Shipman, H., \& Letts, W. (2004). How some college students represent their understandings of the nature of scientific theories? International Journal of Science Education, 26 (6), 735-755. http://dx.doi.org/10.1080/0950069032000138806

Driver, R., Leach, J., Millar, R., \& Scott P. (1996). Young peoples’ images of science. Buchingham: Open University Press.

Erickson, Fr. (1998). Qualitative Research Methods for Science Education. In B. Fraser and K. Tobin (Ed.), International Handbook of Science Education (pp.1155-1174). Dordrecht, Netherlands: Kluwer Academic Publishers.

Faraday, M. (1936/2008). Faraday's Diary of Experimental Investigation 1820-1862, Vol.I, ISBN 978-0-9819083-1-1.

Gilbert, J., Pietrocola, M., Zylbersztajn, A., \& Franco, C. (2000). Science and Education: Notions of Reality, Theory and Model. In J. Gilbert \& C. Boulter (Ed.), Developing Models in Science Education (pp. 19-40). Dordrecht, Netherlands: Kluwer Academic Publishers.

Grosslight, L., Unger, Chr., Jay, E., \& Smith, C. (1991). Understanding Models and their Use in Science: Conceptions of Middle and High School Students and Experts. Journal of Research in Science Teaching, 28 (9), 799-822. http://dx.doi: 10.1002/tea.3660280907

Hipkins, R., Barker, M., \& Bolstad, R. (2005). Teaching the 'nature of science': modest adaptations or radical reconceptions? International Journal of Science Education, 27 (2), 243-254. http://dx.doi.org/10.1080/0950069042000276758

Irez, S. (2006). Are we prepared? An Assessment of Preservice Science Teacher Educators' Beliefs about Nature of Science. Science Teacher Education, 90(6), 1113-1143. http://dx.doi: $10.1002 /$ sce. 20156

Justi, R., \& Gilbert, J. (2002). Science teachers' knowledge about and attitudes towards the use of models and modeling in learning science. International Journal of Science Education, 
24 (12), 1273-1290. http://dx.doi.org/10.1080/09500690210163198

Justi, R., \& Gilbert, J. (2003). Teachers' views on the nature of models. International Journal of Science Education, 25(11), 1369-1386. http://dx.doi.org/10.1080/0950069032000070324

Kalkanis, G.Th. (2002). Educational Physics; From microcosmos to macrocosmos, ISBN 960-90946-3-5 (In Greek).

Komorek, M., \& Duit, R. (2004). The teaching experiment as a powerful method to develop and evaluate teaching and learning sequences in the domain of non-linear systems. International Journal of Science Education, 26(5), 619-633. http://dx.doi.org/10.1080/09500690310001614717

Koulaidis, V., \& Ogborn, J. (1989). Philosophy of science: An empirical study of teachers' views. International Journal of Science Education, 11(2), 173-184. http://dx.doi.org/10.1080/0950069890110206

Koulaidis, V., \& Ogborn, J. (1995). Science Teachers' philosophical assumptions: how well do we understand them? International Journal of Science Education. 17(3), 273-283. http://dx.doi.org/10.1080/0950069950170301

Lederman, N., \& O’Malley, M. (1990). Students' perception of tentativeness in science: Development, use, and sources of change. Science Education, 74(2), 225-239. http://dx.doi: $10.1002 /$ sce. 3730740207

Lederman, N. (2006). Nature of Science: Past, Present and Future. In S. Abell and N. Lederman (Ed.), Handbook of Research on Science Education (pp. 831-880). New Jersey, NJ: Lawrence Erlbaum Associate.

Mackay, L. (1971). Development of Understanding about the Nature of Science. Journal of Research in Science Teaching, 8(1), 57-66. http://dx.doi: 10.1002/tea.3660080110

Matthews, M. (1992). History, philosophy and science teaching: The present rapprochement. Science \& Education, 1(1), 11-48. http://dx.doi:10.1007/BF00430208

Matthews, M. (2007). Models in science and in science education: an introduction. Science \& Education, 16(7), 647-652. http://dx/doi:10.1007/s11191-007-9089-3

Maxwell, J. C. (1855-1856). On Faraday's lines of force, Scientific Papers 1, 155-229. In W. D. Niven (Ed.), Cambridge, Cambridge: Cambridge University Press.

Maxwell, J. C. (1861-1862). On Physical Lines of Force. Philosophical Magazine, 21\&23, Series 4, Part I \& II; III \& IV (Wikisource)

Maxwell, J. C. (1865). A Dynamical Theory of Electromagnetic Field. Philosophical Transactions, 155, 459-512.

Maxwell, J. C. (1873). A treatise on electricity and magnetism, 2 Vol. Oxford, Oxford: Clarendon Press Series.

Mayring, Ph. (2000). Qualitative Content Analysis. In: Forum: Qualitative Social Research, 1 
(2), 20 .

McComas, M., Almazroa, H., \& Clough, M. (1998). The Nature of Science in Science Education: An Introduction. Science \& Education, 7(6), 511-532. http://dx.doi:10.1023/A:1008642510402

Meyling, H. (1997). How to change students' conceptions of the epistemology of science. Science \& Education, 6(4), 397-416. http://dx.doi:10.1023/A:1017908916810

Millar, R., \& Osborne, J. (1998). Beyond 2000: Science Education for the Future. London, London: King's College.

National Research Council (NRC). (1996). National Science Education Standards. Washington, Washington: National Academy Press.

NGSS Lead States. (2013). Next Generation Science Standards: For States, by States. Understanding the Scientific Enterprise: The Nature of Science in the Next Generation Science Standards. (Online) Available: http://www.nextgenscience.org/ (January 20, 2017)

National Research Council (NRC) (2012). A framework for K-12 science education: Practices, crosscutting concepts and core ideas. Washington, DC: National Academy Press.

Organization for the Economic Cooperation and Development (OECD). (2009). The PISA 2003 assessment framework - mathematics, reading, science and problem solving knowledge and skills. (Online) Available: http://www.oecd.org/pisa/pisaproducts/pisa2003/pisa2003assessmentframeworkmathematicsr eadingscienceandproblemsolvingknowledgeandskills-publications2003.htm (January 20, 2017)

Rubba, P., \& Andersen, H. (1978). Development of an Instrument to Assess Secondary School Students' Understanding of the Nature of Scientific Knowledge. Science Education, 62 (4), 449-458. http://dx.doi: 10.1002/sce.3730620404

Stavrou, D., Duit, R., \& Komorek, M. (2008). A teaching and learning sequenFFce about the interplay of chance and determinism in nonlinear systems. Physics Education, 43(4), 417-422.

Treagust, D., Chittleborough, G., \& Mamiala, Th. (2002): Students' understanding of the role of scientific models in learning science. International Journal of Science Education, 24(4), 357-368. http://dx.doi.org/10.1080/09500690110066485

Van Driel, J., \& Verloop, N. (1999). Teachers' knowledge of models and modeling in science. International Journal of Science Education, 21(11), 1141-1153. http://dx.doi.org/10.1080/095006999290110

Van Driel, J., \& Verloop, N. (2002). Experienced teachers' knowledge of teaching and learning of models and modelling in science education. International Journal of Science Education, 24(12), 1255-1272. http://dx.doi.org/10.1080/09500690210126711 
Appendix

Appendix 1. Teaching sequences

\begin{tabular}{|c|c|c|c|}
\hline Interview & $\begin{array}{l}\text { Science } \\
\text { Content }\end{array}$ & $\begin{array}{l}\text { Conceptual steps } \\
\text { followed }\end{array}$ & Teaching material \\
\hline $\begin{array}{l}1^{\text {st }}: \text { Law of } \\
\text { nature }\end{array}$ & $\begin{array}{l}\text { A natural law is } \\
\text { a generalization } \\
\text { that holds true } \\
\text { universally, has } \\
\text { empirical } \\
\text { content, } \\
\text { belongs to a } \\
\text { wider system of } \\
\text { knowledge } \\
\text { (theory), and } \\
\text { has limits in its } \\
\text { application } \\
\text { (Anapolitanos } \\
\text { et al., 2003, p. } \\
\text { 80-83). }\end{array}$ & $\begin{array}{l}\text { a. Expectation } \\
\text { and } \\
\text { prediction. } \\
\text { b. Developing } \\
\text { the } \\
\text { characteristics } \\
\text { of natural } \\
\text { laws: } \\
\text { universality, } \\
\text { empirical } \\
\text { content and } \\
\text { the distinction } \\
\text { between } \\
\text { incidental } \\
\text { generalization } \\
\text { and natural } \\
\text { law through } \\
\text { possible } \\
\text { relation to a } \\
\text { theory. } \\
\text { c. Law power } \\
\text { limits: } \\
\text { distinction } \\
\text { between the } \\
\text { ontological } \\
\text { and epistemologic } \\
\text { al aspects of } \\
\text { laws. } \\
\text { d. Conclusion. }\end{array}$ & $\begin{array}{l}\text { Worksheets containing situations } \\
\text { from everyday life are used: } \\
\text { students discuss whether they are } \\
\text { laws of nature. For example, } \\
\text { students are given the situation } \\
\text { "During a cold winter day, I } \\
\text { couldn't find a taxi". Can we say } \\
\text { that "During the cold winter } \\
\text { days, taxis do not circulate" is a } \\
\text { law of nature? } \\
\text { After that, students are given the } \\
\text { next situation: "Every cold } \\
\text { winter day, I couldn't find a taxi" } \\
\text { and asked if the phrase "During } \\
\text { cold winter days, taxis do not } \\
\text { circulate" is a law. } \\
\text { After that, they are asked the } \\
\text { same question regarding the } \\
\text { phrase: "Whenever the magnetic } \\
\text { flux passing through a loop } \\
\text { varies, voltage induction appears } \\
\text { in the loop ends". } \\
\text { Finally, students are given } \\
\text { examples of laws with limited } \\
\text { power (e.g., Newton's Laws) as } \\
\text { opposed to more general laws } \\
\text { (e.g., Einstein's } \\
\text { Relativity) in order to discuss } \\
\text { and conclude on the issue of } \\
\text { laws' power. }\end{array}$ \\
\hline $\begin{array}{l}2^{\text {nd }} \\
\text { Scientific } \\
\text { theory }\end{array}$ & $\begin{array}{l}\text { A scientific } \\
\text { theory is a } \\
\text { conceptual } \\
\text { scheme } \\
\text { supported by }\end{array}$ & $\begin{array}{l}\text { a. Expectation } \\
\text { and prediction. } \\
\text { b. Further } \\
\text { expression of } \\
\text { opinion }\end{array}$ & $\begin{array}{l}\text { Students are given worksheets } \\
\text { containing: } \\
\text { a. Maxwell's equations in } \\
\text { qualitative form. } \\
\text { Students consider them }\end{array}$ \\
\hline
\end{tabular}




\begin{tabular}{|c|c|c|c|}
\hline & $\begin{array}{l}\text { and based on } \\
\text { facts, } \\
\text { observations } \\
\text { and } \\
\text { experiments, } \\
\text { To explain a } \\
\text { phenomenon ... } \\
\text { and predict } \\
\text { future } \\
\text { observations } \\
\text { (McComas, } \\
\text { 2003, p. 148). }\end{array}$ & $\begin{array}{l}\text { regarding the } \\
\text { notion of } \\
\text { scientific } \\
\text { theory. } \\
\text { c. Developing } \\
\text { scientific } \\
\text { theory's } \\
\text { characteristics: } \\
\text { based on } \\
\text { observations, } \\
\text { facts } \\
\text { experiments, a } \\
\text { scientific } \\
\text { theory not only } \\
\text { explains but } \\
\text { predicts } \\
\text { phenomena as } \\
\text { well. } \\
\text { d. Conclusion. }\end{array}$ & $\begin{array}{l}\text { and say if they constitute } \\
\text { a theory and why. } \\
\text { b. Historical text excerpts } \\
\text { from Treatise on } \\
\text { Electromagnetism II } \\
\text { (Maxwell, 1873, par. } \\
\text { 475, p. 128 and par. 528, } \\
\text { p. 162) which reveal the } \\
\text { influences of Oersted and } \\
\text { Faraday on Maxwell's } \\
\text { work. Students think } \\
\text { about and discuss the } \\
\text { empirical content of a } \\
\text { theory. } \\
\text { c. Historical text excerpts } \\
\text { from Treatise on } \\
\text { Electromagnetism } \\
\text { (Maxwell 1873, par. } 781 \text {, } \\
\text { p. 383) in which } \\
\text { Maxwell states that his } \\
\text { theory is intended both to } \\
\text { explain and to predict } \\
\text { phenomena. }\end{array}$ \\
\hline $\begin{array}{l}3^{\text {rd }} \\
\text { Scientific } \\
\text { model }\end{array}$ & $\begin{array}{l}\text { A model in } \\
\text { science is a } \\
\text { representation } \\
\text { of an idea, an } \\
\text { object, an } \\
\text { event, a process } \\
\text { or a system and } \\
\text { its purpose is to } \\
\text { simplify and } \\
\text { explain (Gilbert } \\
\text { et al 2000, p. } \\
\text { 11). }\end{array}$ & $\begin{array}{l}\text { a. Expectation } \\
\text { and prediction. } \\
\text { b. Expressing } \\
\text { examples and } \\
\text { formulating the } \\
\text { basic } \\
\text { characteristics } \\
\text { of models } \\
\text { (representation } \\
\text { and } \\
\text { simplification) } \\
\text { c. Examining } \\
\text { models and } \\
\text { non-models in } \\
\text { order to } \\
\text { distinguish } \\
\text { between them. } \\
\text { d. Further }\end{array}$ & $\begin{array}{l}\text { Students are given worksheets } \\
\text { containing pictures of different } \\
\text { kinds of models (objects, graphs, } \\
\text { equations, etc.) and non-models } \\
\text { (e.g., photos). They are asked to } \\
\text { discuss them in order to } \\
\text { distinguish between models and } \\
\text { non-models and to develop } \\
\text { criteria for identifying models. }\end{array}$ \\
\hline
\end{tabular}




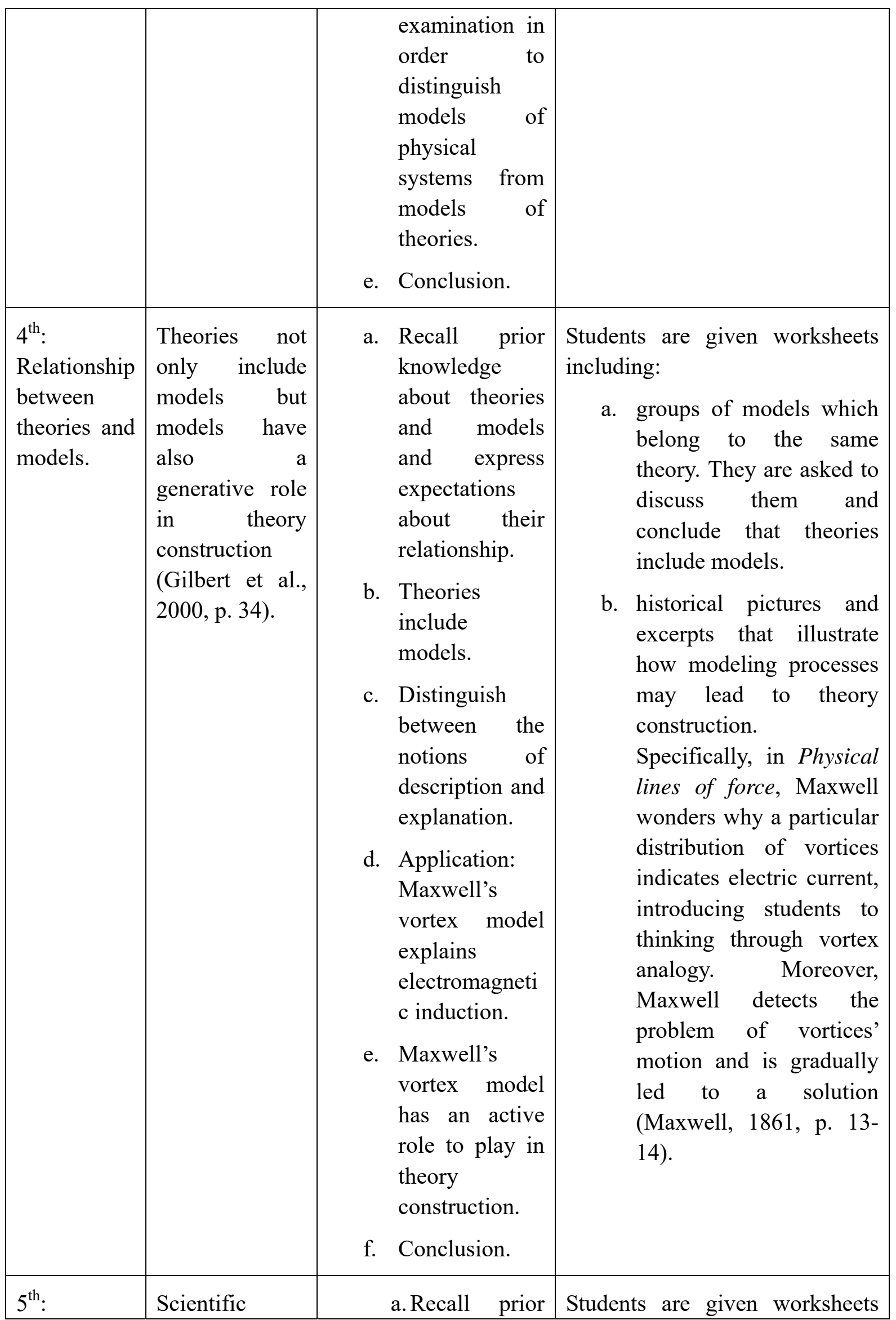




\begin{tabular}{|c|c|c|c|}
\hline $\begin{array}{l}\text { Relationship } \\
\text { between } \\
\text { theories and } \\
\text { laws. }\end{array}$ & 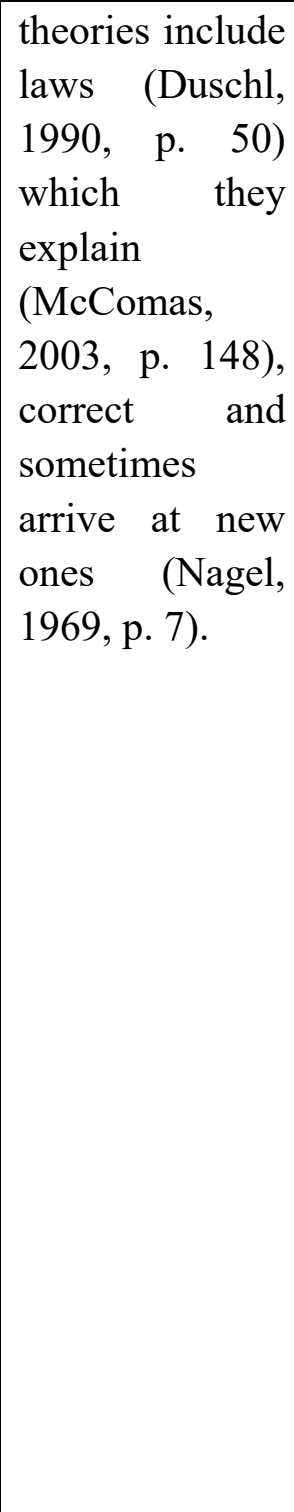 & $\begin{array}{l}\text { knowledge } \\
\text { about } \\
\text { theories and } \\
\text { laws and } \\
\text { express } \\
\text { expectation } \\
\text { about their } \\
\text { relationship. } \\
\text { b. Theories } \\
\text { include } \\
\text { laws. } \\
\text { c. Theories } \\
\text { explain } \\
\text { laws. } \\
\text { d. Theories } \\
\text { correct } \\
\text { laws. } \\
\text { e. From } \\
\text { explanation } \\
\text { and } \\
\text { correction } \\
\text { to } \\
\text { prediction } \\
\text { of } \\
\text { laws. } \\
\text { f. Conclusion. }\end{array}$ & $\begin{array}{l}\text { including: } \\
\text { a. Maxwell's e/m equations } \\
\text { in order for students to } \\
\text { formulate the relationship } \\
\text { between e/m theory and } \\
\text { the correspondent laws. } \\
\text { b. Maxwell's historical text } \\
\text { excerpts (Maxwell, 1861, } \\
\text { p. } 13 \text { and p. 14) showing } \\
\text { that Maxwell aimed at } \\
\text { explaining the law of e/m } \\
\text { induction. } \\
\text { c. Maxwell's historical text } \\
\text { excerpts (Maxwell, 1861, } \\
\text { p. 34) showing that } \\
\text { Maxwell wanted to } \\
\text { correct and expand } \\
\text { Ampere's law. } \\
\text { d. Maxwell's historical text } \\
\text { excerpt (Maxwell, 1861, } \\
\text { p. 34) showing that } \\
\text { Maxwell's e/m theory } \\
\text { predicted the nature of } \\
\text { light. }\end{array}$ \\
\hline $\begin{array}{l}6^{\text {th }} \text { : } \\
\text { Relationship } \\
\text { between } \\
\text { laws and } \\
\text { models. }\end{array}$ & $\begin{array}{l}\text { Laws are } \\
\text { specified by } \\
\text { mathematical } \\
\text { models that } \\
\text { permit } \\
\text { sufficient } \\
\text { precision and } \\
\text { may lead to } \\
\text { predictions } \\
\text { (Malvern, } \\
\text { 2000, p. 62). }\end{array}$ & $\begin{array}{l}\text { a. Recall prior } \\
\text { knowledge } \\
\text { about models } \\
\text { and laws and } \\
\text { express } \\
\text { expectation } \\
\text { about their } \\
\text { relationship. } \\
\text { b. Mathematical } \\
\text { models are } \\
\text { precise. } \\
\text { c. Mathematical } \\
\text { models } \\
\text { contribute to }\end{array}$ & $\begin{array}{l}\text { Students are given worksheets } \\
\text { including: } \\
\text { a. an excerpt from } \\
\text { Faraday's diary (29 } \\
\text { August 1831, 367-392) } \\
\text { regarding the production } \\
\text { of electricity from } \\
\text { magnetism. It is a fully } \\
\text { descriptive text with no } \\
\text { formalism, allowing the } \\
\text { students to comment on } \\
\text { this kind of scientific text } \\
\text { and express their opinion } \\
\text { on the importance of }\end{array}$ \\
\hline
\end{tabular}




\begin{tabular}{|c|c|c|c|}
\hline & & $\begin{array}{ll} & \text { further } \\
\text { conclusions. } & \\
\text { d. Conclusion. }\end{array}$ & $\begin{array}{l}\text { mathematisation. } \\
\text { b. an excerpt from The } \\
\text { Character of Physical } \\
\text { Law (Feyman, 1985, p. } \\
\text { 58) in order to formulate } \\
\text { a view about the value of } \\
\text { mathematical model in } \\
\text { the expression of laws. } \\
\text { c. an excerpt from A } \\
\text { dynamical theory for } \\
\text { electromagnetic field } \\
\text { (Maxwell, 1865, p. 466), } \\
\text { in which Maxwell } \\
\text { acknowledges that } \\
\text { Faraday would have } \\
\text { arrived at the e/m } \\
\text { theory of light if he had } \\
\text { used the appropriate } \\
\text { mathematical tools. } \\
\text { Maxwell could have } \\
\text { excluded further } \\
\text { conclusions about the } \\
\text { nature of the light, thanks } \\
\text { to his mathematization of } \\
\text { Faraday's theory on e/m } \\
\text { induction. }\end{array}$ \\
\hline
\end{tabular}

\section{Copyright Disclaimer}

Copyright for this article is retained by the author(s), with first publication rights granted to the journal.

This is an open-access article distributed under the terms and conditions of the Creative Commons Attribution license (http://creativecommons.org/licenses/by/3.0/). 